\title{
COMPARISON OF THE BIOCOMPATIBILITY OF DIFFERENT ROOT CANAL IRRIGANTS
}

\author{
João Eduardo GOMES-FILHO', Kamila Guilherme AURÉLIO², \\ Mariana Machado Teixeira de Moraes COSTA ${ }^{3}$, Pedro Felício Estrada BERNABÉ ${ }^{4}$
}

\author{
1- DDS, MSc, PhD, Associate Professor, Department of Restorative Dentistry, Dental School of Araçatuba, São Paulo State University \\ Araçatuba, SP, Brazil. \\ 2- DDS Undergraduate Student, Department of Restorative Dentistry, Dental School of Araçatuba, São Paulo State University, Araçatuba, SP, \\ Brazil. \\ 3- DDS, MSc, Graduate Student, Department of Restorative Dentistry, Dental School of Araçatuba, São Paulo State University, Araçatuba, SP, \\ Brazil. \\ 4- DDS, MSc, PhD, Chair Professor, Department of Restorative Dentistry, Dental School of Araçatuba, São Paulo State University, Araçatuba, \\ SP, Brazil.
}

Corresponding address: Prof. Dr. João Eduardo Gomes Filho - Department of Restorative Dentistry - School of Dentistry, São Paulo State University - Rua José Bonifácio, 1193 - 16015-050 Araçatuba, SP, Brazil - Phone: +55-18-3636-3253. Fax: +55-18-3636-3332.

e-mail: joao@foa.unesp.br

Received: August 13, 2007 - Modification: November 28, 2007 - Accepted: January 15, 2008

\begin{abstract}
$\Gamma_{\text {h }}$

purpose of this study was to compare the reaction of rat subcutaneous connective tissue to $0.9 \%$ sterile saline, $2.5 \%$ sodium hypochlorite $(\mathrm{NaOCl}), 5.25 \% \mathrm{NaOCl}$ and $2 \%$ chlorhexidine gluconate solution or gel. Six circles were demarcated on the dorsal skin of 24 male Wistar rats, leaving $2 \mathrm{~cm}$ between each circle. Using a syringe, $0.1 \mathrm{~mL}$ of each root canal irrigant was injected subcutaneously into 5 circles. In the 6th circle, the needle of an empty syringe was introduced into the skin, but no irrigant was injected (control group). Evaluations were undertaken at $2 \mathrm{~h}, 48 \mathrm{~h}, 14$ days and 30 days post-procedure. Tissue samples were excised, embedded in paraffin blocks and 3- $\mu \mathrm{m}$-thick sections were obtained and stained with hematoxylin and eosin. The areas of inflammatory reaction were evaluated and analyzed statistically by ANOVA and Tukey's test. The control group showed few or no inflammatory reaction areas in the subcutaneous tissue. $0.9 \%$ saline solution, $2.0 \%$ chlorhexidine solution and $2.5 \% \mathrm{NaOCl}$ showed a good biocompatibility, as very mild inflammatory reaction was detected at 14 days and tissue repair occurred at 30 days. $5.25 \% \mathrm{NaOCl}$ was the most toxic irrigant, as the number of inflammatory cells remained elevated at 14 and 30 days. The group treated with $2.0 \%$ chlorhexidine gluconate gel presented a moderate inflammatory response at 14 days, which decreased at 30 days, being considered similar to that of the control group, $0.9 \%$ saline solution, $2.0 \%$ chlorhexidine solution and $2.5 \% \mathrm{NaOCl}$ at this experimental period.
\end{abstract}

Key words: Root canal irrigants. Sodium hypochlorite. Chlorhexidine. Biocompatibility.

\section{INTRODUCTION}

One of the goals of root canal treatment is to eliminate bacteria, bacterial products and debris from the root canal system $^{21}$. Most bacteria found in the canal space may be removed by the mechanical action of endodontic instruments. However, in several situations, due to the complex anatomy of the root canal system, organic residues and bacteria lodged deep inside the dentinal tubules cannot be reached even after careful mechanical instrumentation ${ }^{6,25}$. In these cases, the use of irrigating solutions is essential to ensure bacterial minimization ${ }^{12,14}$ and elimination of organic tissue remnants ${ }^{29}$.

Numerous products are currently used as endodontic irrigants, such as sodium hypochlorite $(\mathrm{NaOCl})$, chlorhexidine gluconate, calcium hydroxide and saline $\mathrm{e}^{1,2,4,5,10,12-14,18,19,21,24,26-}$ ${ }^{28}$. Each product has different properties and several studies have compared their antimicrobial effect, chemical properties and biocompatibility to establish an ideal solution to be used as an adjuvant to root canal treatment. It is highly desirable that the chemical agents selected as endodontic irrigants possess favorable properties, such as antimicrobial activity and dissolution of organic tissues, assist in root canal system debridement and induce a favorable reaction in the periapical tissues $^{24,27}$.

$\mathrm{NaOCl}$ is one of the most popular and widely used endodontic irrigants due to its antibacterial activity and capacity of dissolving necrotic tissue remanants ${ }^{23}$. The antimicrobial effect of $\mathrm{NaOCl}$ results from the formation of hypochlorous acid $(\mathrm{HOCl})$, when in contact with organic debris. $\mathrm{HOCl}$ exerts its effect by oxidation of sulphydryl groups within bacterial enzyme systems, thereby disrupting the microbial metabolism ${ }^{23}$. Although it is an effective antibacterial 
agent, $\mathrm{NaOCl}$ is harmful outside the root canal and causes damage when in contact with the periradicular tissues ${ }^{3,11,27}$.

Chlorhexidine gluconate has also been suggested as an effective irrigating solution and should be used as an alternative to $\mathrm{NaOCl}^{17}$. This solution, by attaching to bacterial cytoplasmic membranes, disrupts the osmotic balance, resulting in leakage of intracellular material ${ }^{10}$. It also binds to hydroxyapatite and soft tissues, changing their electrical field to compete with bacterial binding ${ }^{15}$. In addition, chlorhexidine gluconate presents a residual antibacterial effect on the infected canals, which is a favorable characteristic ${ }^{4,5,12}$. However, this antibacterial agent has always been used in a liquid presentation and its inability to dissolve pulp rests has been a problem in some situations. Some attempts have been made to overcome this deficiency by the combined use of $\mathrm{NaOCl}$ and chlorhexidine ${ }^{14}$ or the use of chlorhexidine gel, which has been shown to present an effective antibacterial effect $^{1,6-9,13,18,28}$ and a good performance as an intracanal medication $^{21,22}$. Nevertheless, little data is available about tissue reaction to chlorhexidine gel and further research should be undertaken to validate its use as an irrigating solution during endodontic treatment.

Thus, the purpose of the present study was to compare the reaction of rat subcutaneous connective tissue to $0.9 \%$ sterile saline, $2.5 \% \mathrm{NaOCl}, 5.25 \% \mathrm{NaOCl}, 2 \%$ chlorhexidine gluconate solution and $2 \%$ chlorhexidine gluconate gel.

\section{MATERIALS AND METHODS}

The cytotoxic effects of the root canal irrigants on the subcutaneous tissue of rats were examined using previously described methodologies ${ }^{19,27,30}$. Twenty-four male Wistar rats weighing 250-270 g were used for in vivo experiments. The animals were housed in a temperature-controlled environment with water and food ad libitum. All experiments were conducted in accordance with the National Institute of Healthy (NIH) guidelines on the welfare of experimental animals and after approval by the Ethics in Research Committee of the Dental School of Araçatuba, São Paulo State University.

Subcutaneous rat tissue reaction to the following irrigating solutions was evaluated: $0.9 \%$ sterile saline; $2.5 \%$ $\mathrm{NaOCl} ; 5.25 \% \mathrm{NaOCl} ; 2.0 \%$ chlorhexidine gluconate solution; $2.0 \%$ chlorhexidine gluconate gel.

Under general anesthesia with xylazine $(10 \mathrm{mg} / \mathrm{kg}$ body weigth) and $5 \%$ ketamine hydrochloride $(25 \mathrm{mg} / \mathrm{kg}$ body weigth), the dorsal skin of the animals was shaved and cleaned with $10 \%$ iodine solution. Using a glass template, 6 circles were demarcated on the dermis of each rat leaving $2 \mathrm{~cm}$ between each circle. Using a syringe, $0.1 \mathrm{~mL}$ of each root canal irrigant was injected subcutaneously into 5 circles. For the control group, the needle of an empty syringe was introduced in the 6th circle, but no irrigant was injected. Evaluations were made 2 h, 48 h, 14 days and 30 days after injection.

In each examination period, 6 animals from experimental groups were sacrificed by anesthetic overdose. The dorsal skin was shaved and tissue specimens were excised with a scalpel, stored in $10 \%$ formalin solution for $48 \mathrm{~h}$, washed in running water to remove traces of the fixating solution and thereafter embedded in paraffin blocks using standard procedures. Three-micrometer-thick sections were obtained from the paraffin-embedded specimens and stained with hematoxylin and $\operatorname{eosin}^{13}$. From each tissue sample, 5 sections presenting the greatest inflammatory reaction were examined with a light microscope (Olympus Corporation Ina Plant, Ina, Japan).

The areas of inflammatory reaction were evaluated quantitatively and the number of inflammatory cells was counted under $\mathrm{x} 25$ magnification. To standardize the results, the inflammatory cells (neutrophils, eosinophils, lymphocytes, macrophages, giant cells) were counted using specific software (Leica Qwin V3; Leica Microsystems Imaging Solutions Ltd,. Cambridge, UK). Statistical analysis was performed by ANOVA and Tukey's test (Graph Prism 3.0; Graph Pad Software, San Diego, CA, USA) at 5\% significance level.

\section{RESULTS}

\section{Tissue Reaction to the Solutions over Time}

In the present investigation, the control group (Figure 1) showed few or no inflammatory reaction areas. No significant relationship was observed among the inflammatory reactions at the 4 different evaluation periods for this group $(\mathrm{p}>0.05)$. It was observed a significantly higher inflammatory reaction at the sites injected with the irrigants compared to the site where no irrigant was injected (control) (Table 1).

The sterile saline group (Figure 2) presented a milder inflammatory response than that of the other experimental groups (Table 1). There was a significant increase $(p<0.05)$ in inflammatory response at $48 \mathrm{~h}$ compared to the initial period. A significant decrease in mean number of inflammatory cells was observed at 14 and 30 days, with no statistically significant difference in relation to the initial 2-h period $(\mathrm{p}>0.05)$.

The 2.5\% $\mathrm{NaOCl}$ (Figure 3) and 2.0\% chlorhexidine gluconate solution groups (Figure 4) presented similar results and inflammatory response pattern (Table 1). In both cases, it was observed a mild inflammatory reaction at $2 \mathrm{~h}$. The mean number of inflammatory cells reached the peak at $48 \mathrm{~h}$ remaining moderate up to the 14-day period, with statistically significant difference compared to initial response $(\mathrm{p}<0.05)$. At 30 days, it was observed a significantly decrease in the inflammatory response, with no significant difference compared to the $2-\mathrm{h}$ period ( $\mathrm{p}>0.05$ ).

In the $5.25 \% \mathrm{NaOCl}$ group (Figure 5), the mean inflammatory reaction values were elevated (Table 1 ). The inflammatory response was considered statistically significant at $48 \mathrm{~h}$ and 14 days, compared to the 2 - $\mathrm{h}$ period, and the mean number of inflammatory cells was maintained up to the 30 day period $(\mathrm{p}<0.05)$.

The $2.0 \%$ chlorhexidine gluconate gel group (Figure 6) presented a mild initial inflammatory response that increased 


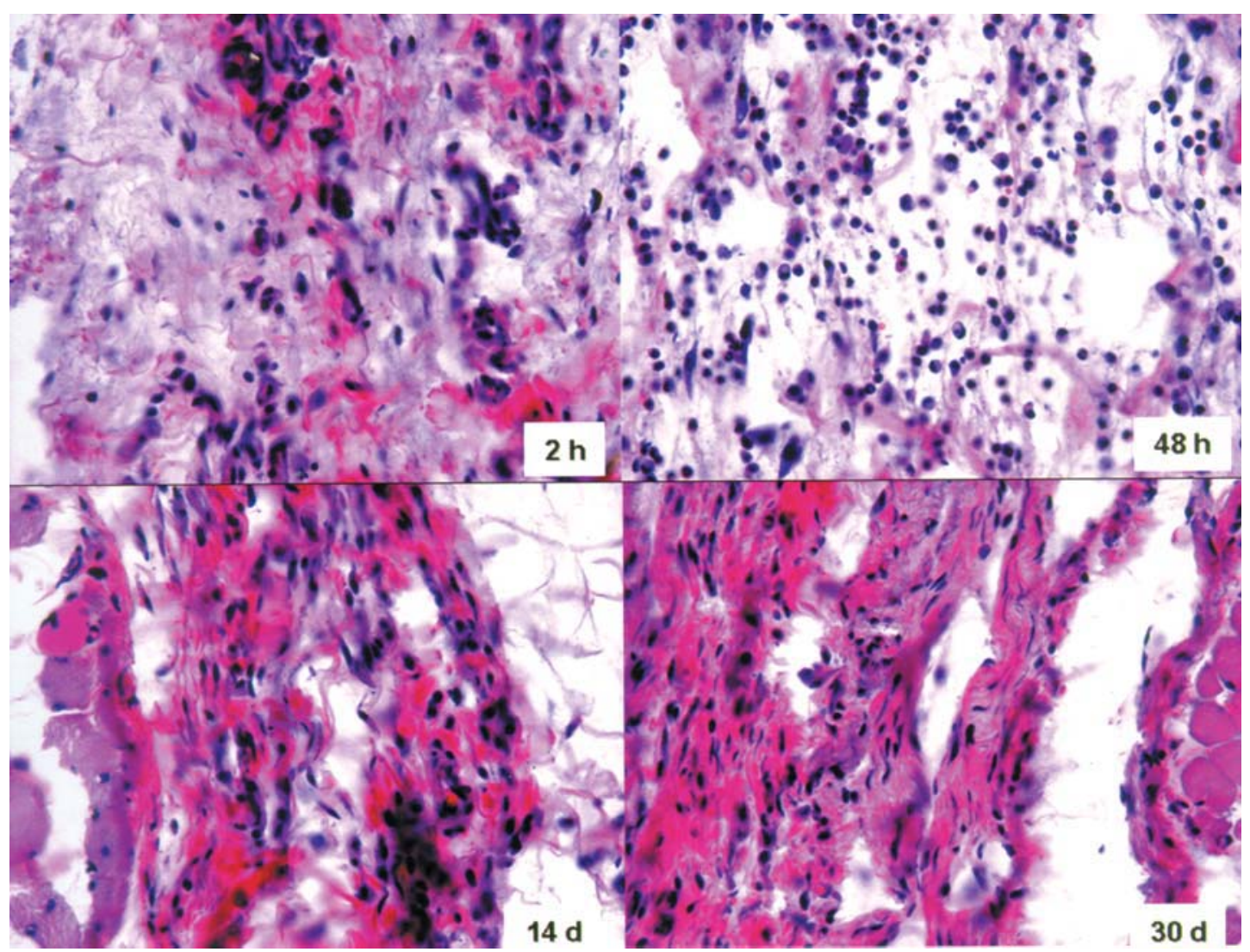

FIGURE 1- Reaction of rat subcutaneous connective tissue to the empty injector (no irrigant) - Control Group (H.E.; x25)

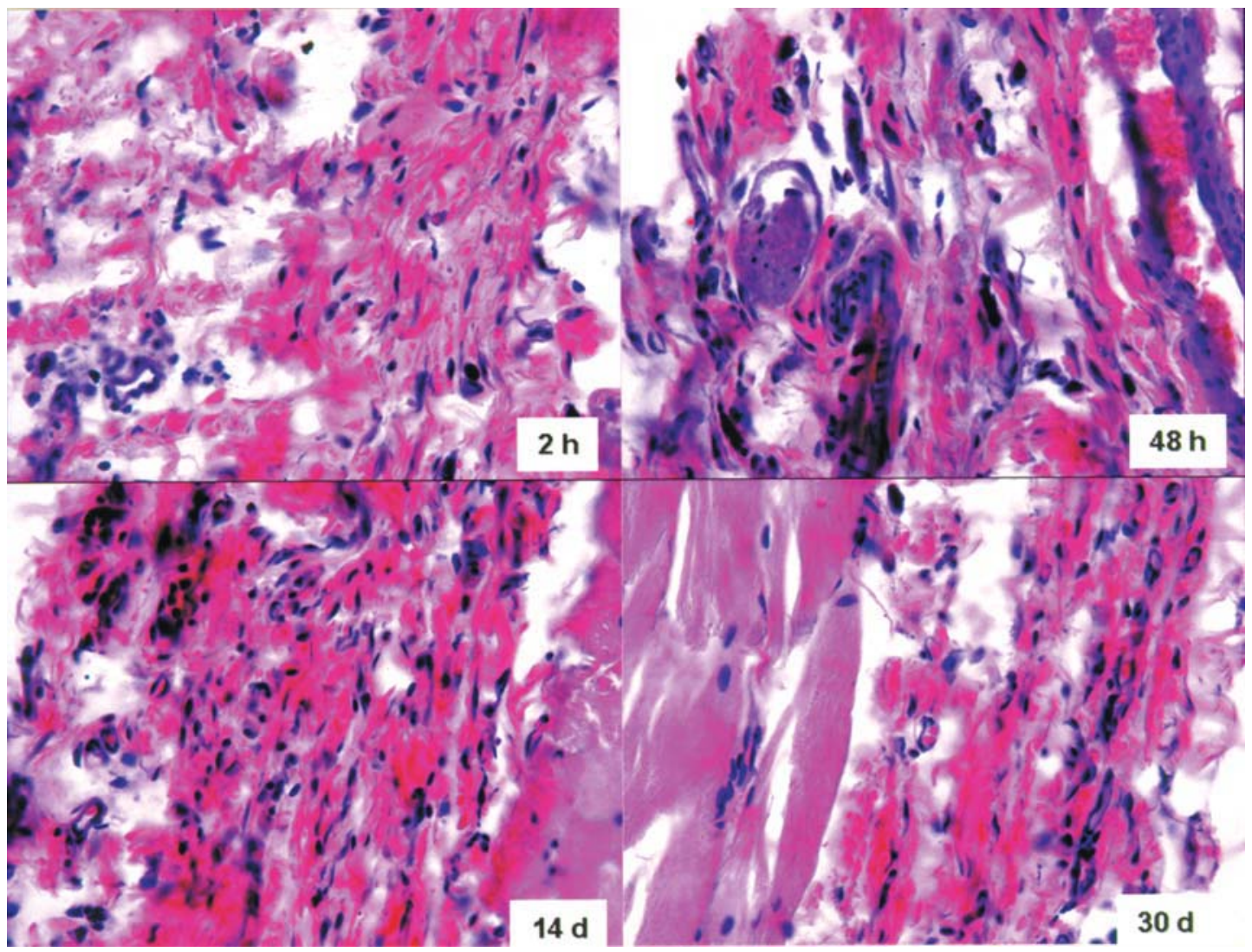

FIGURE 2- Reaction of rat subcutaneous connective tissue to $0.9 \%$ sterile saline (H.E.; x25) 


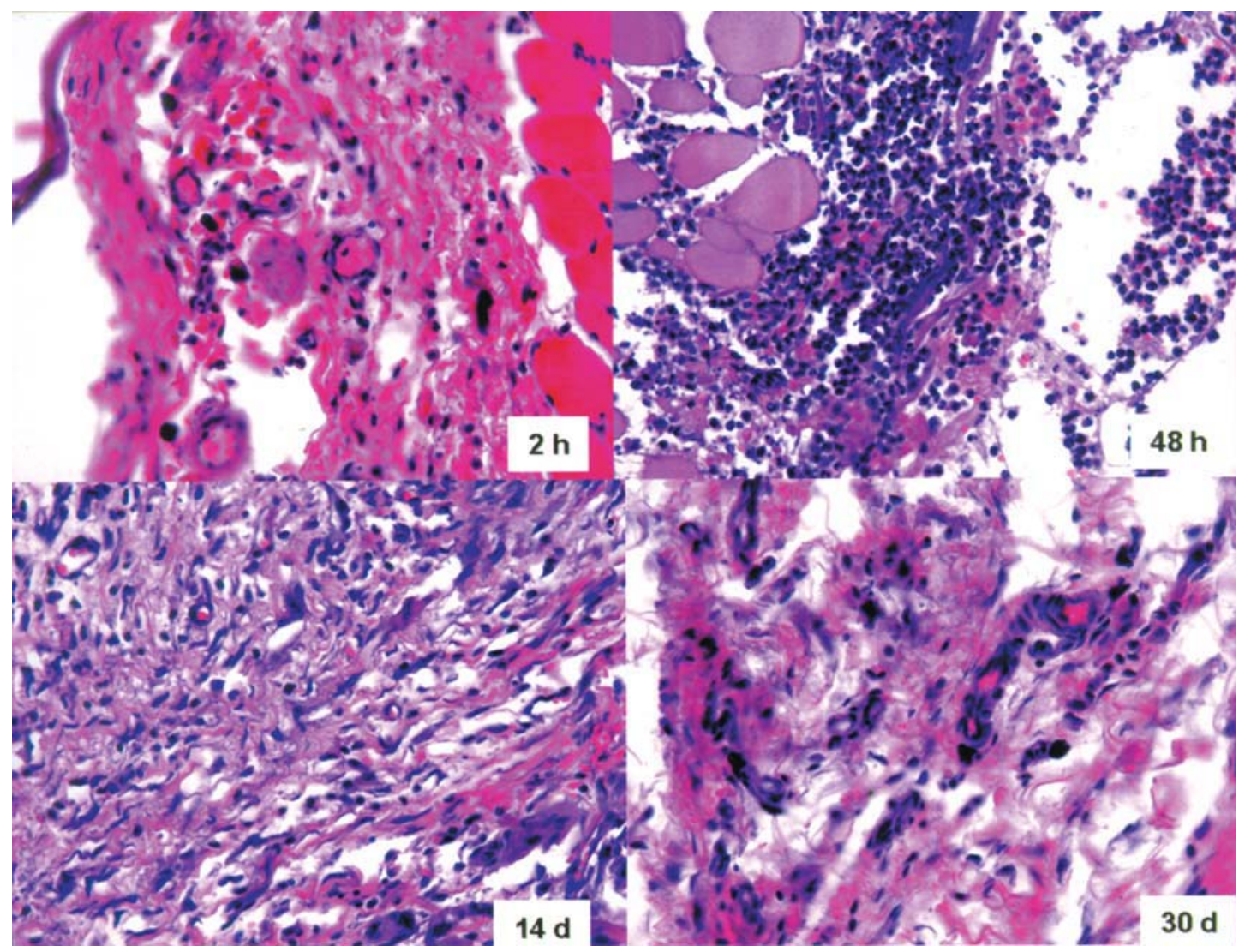

FIGURE 3- Reaction of rat subcutaneous connective tissue to $2.5 \% \mathrm{NaOCl}(\mathrm{H} . \mathrm{E}$.; x25)

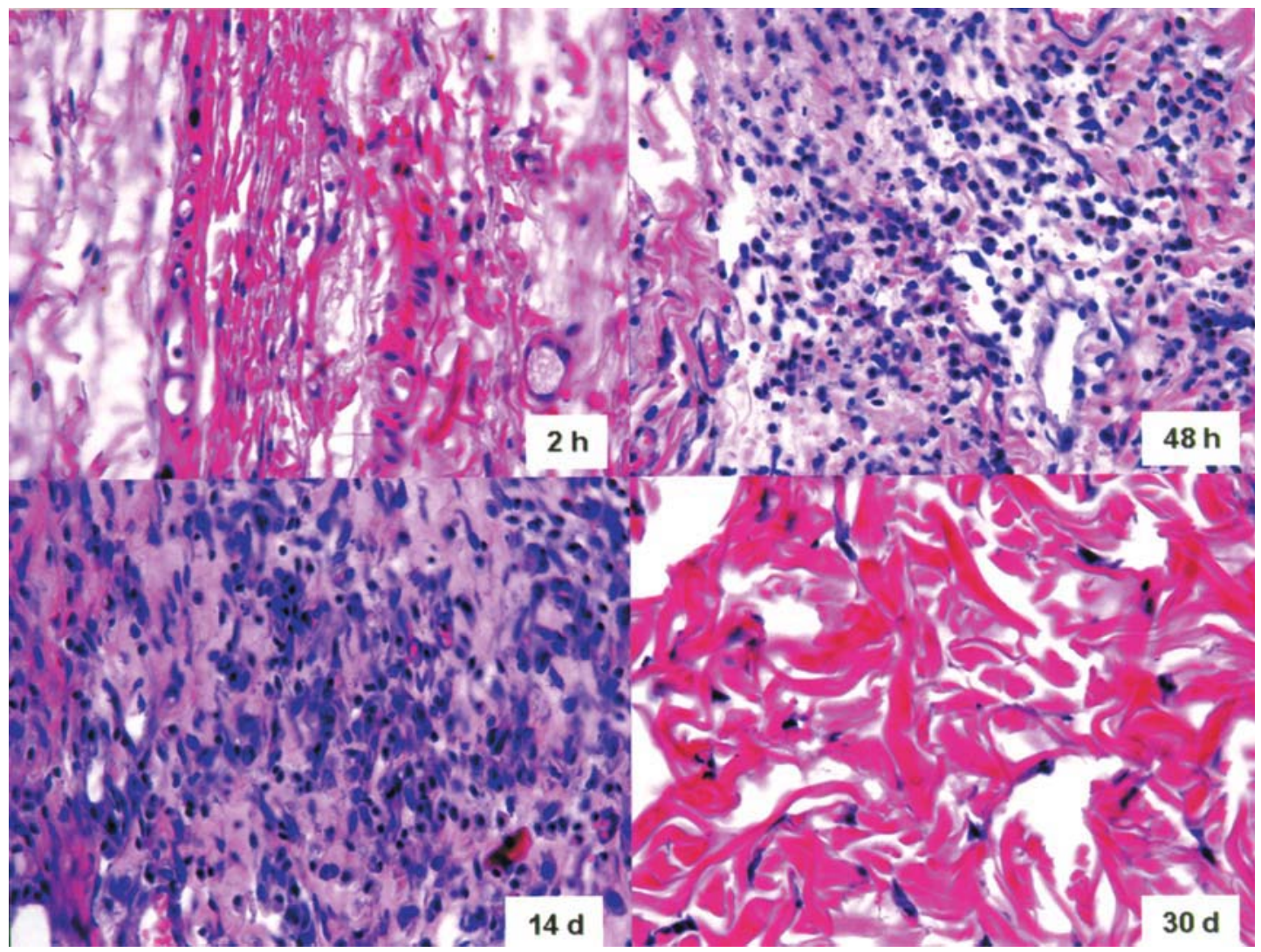

FIGURE 4- Reaction of rat subcutaneous connective tissue to $5.25 \% \mathrm{NaOCl}$ (H.E.; x25) 


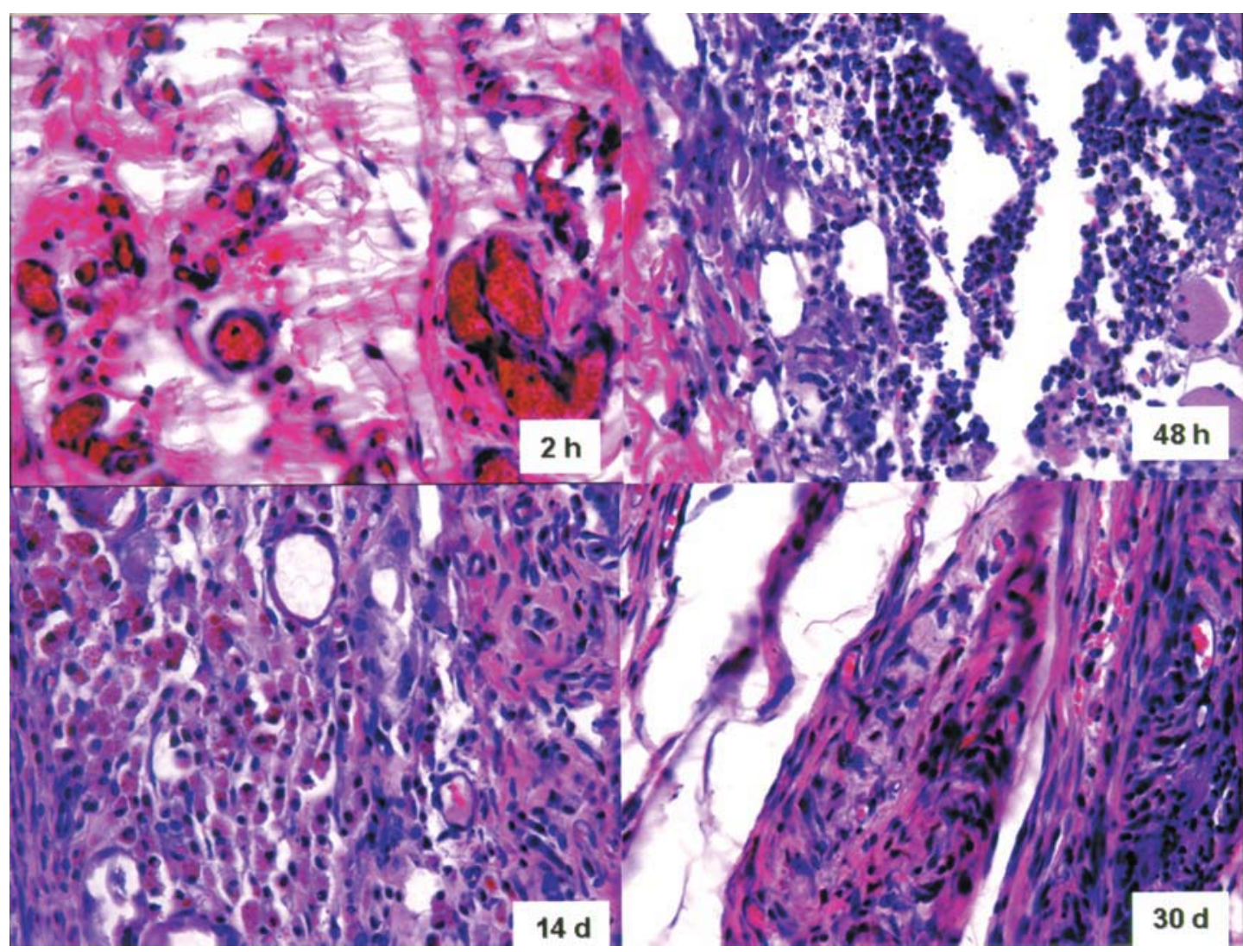

FIGURE 5- Reaction of rat subcutaneous connective tissue to $2.0 \%$ Chlorhexidine solution (H.E.; x25)

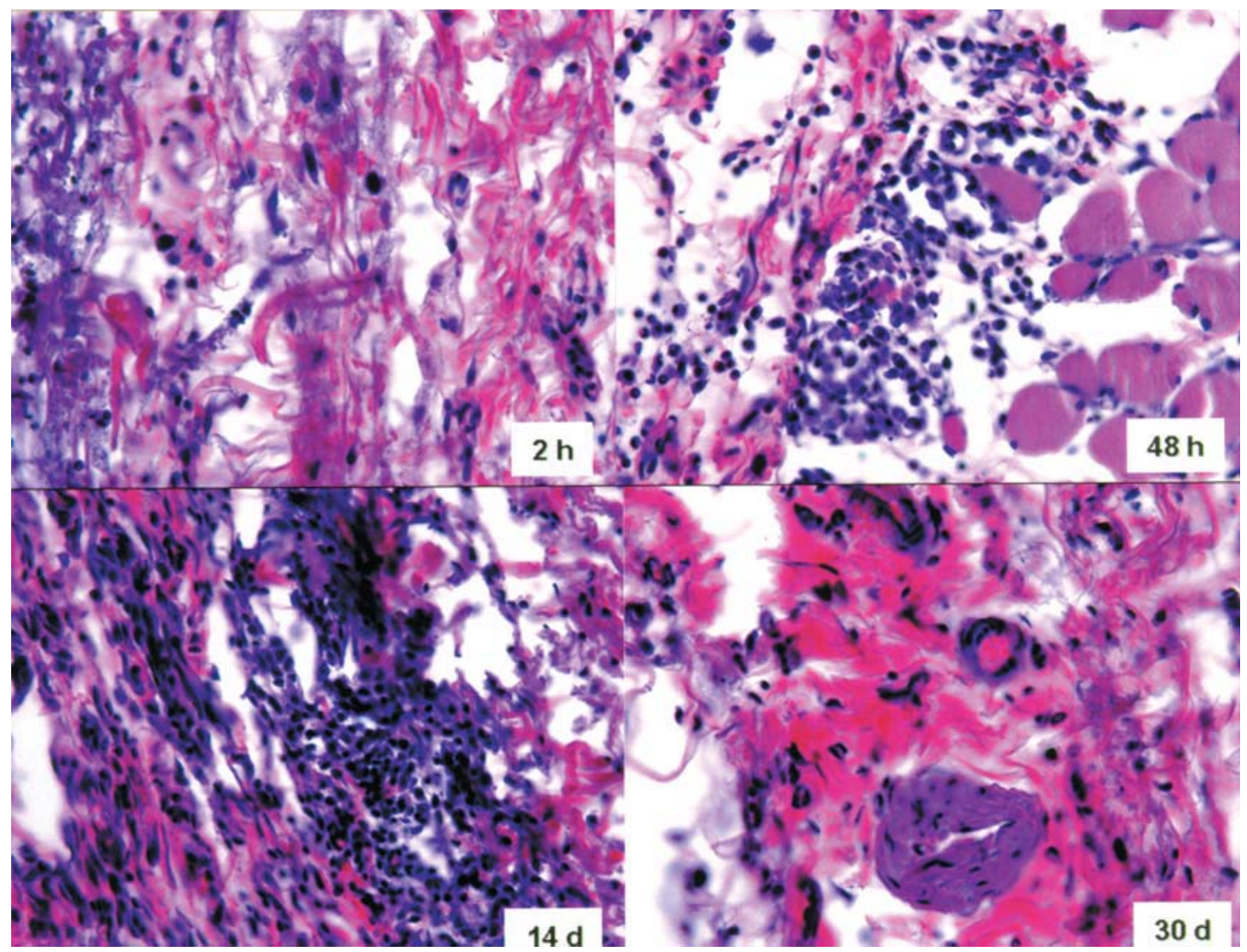

FIGURE 6- Reaction of rat subcutaneous connective tissue to $2.0 \%$ Chlorhexidine gel (H.E.; x25) 
TABLE 1- Mean number of inflammatory cells at the different time periods after injection

\begin{tabular}{|c|c|c|c|c|}
\hline Irrigating solution & $2 \mathrm{~h}$ & $48 \mathrm{~h}$ & 14 days & 30 days \\
\hline Control Group (no irrigant) & $273^{a 1}$ & $301^{\mathrm{a} 1}$ & $306^{\mathrm{a} 1}$ & $285^{\mathrm{a} 1}$ \\
\hline $0.9 \%$ sterile saline & $297^{a 1}$ & $478^{\mathrm{b} 3}$ & $335^{\mathrm{a} 1}$ & $249^{a 1}$ \\
\hline $2.5 \% \mathrm{NaOCl}$ & $263^{a 1}$ & $1068^{d 5}$ & $780^{\mathrm{c3}}$ & $360^{\mathrm{b} 2}$ \\
\hline $5.25 \% \mathrm{NaOCl}$ & $358^{\mathrm{a} 2}$ & $1047^{c 5}$ & $791^{\text {b3 }}$ & $690^{\mathrm{b} 3}$ \\
\hline $2.0 \%$ Chlorhexidine & $298^{a 1}$ & $885^{\mathrm{c4}}$ & $412^{\mathrm{b} 2}$ & $346^{\mathrm{a} 2}$ \\
\hline $2.0 \%$ Chlorhexidine gel & $241^{a 1}$ & $363^{\mathrm{b} 2}$ & $870^{c 3}$ & $315^{\mathrm{a} 2}$ \\
\hline
\end{tabular}

Tissue reaction to the solutions over time - Rows ( $p<0.05$; different letters indicate statistically significant difference at $5 \%$ ). Comparison among the solutions at the evaluation periods - Columns $(p<0.05$; Different indicate statistically significant difference at $5 \%$ ).

significantly $(\mathrm{p}<0.05)$ at $48 \mathrm{~h}$ and 14 days (Table 1$)$. At 30 days, it was observed a decrease in the mean number of inflammatory cells $(\mathrm{p}<0.05)$.

\section{Comparison among the Solutions at the Evaluation Periods}

Comparing all groups (Table 1), it was possible to observe that at $2 \mathrm{~h}$ only the $5.25 \% \mathrm{NaOCl}$ group showed a higher inflammatory response $(\mathrm{p}<0.05)$ compared to the control group. At 48 hours, all experimental groups showed a statistically significant increase of inflammatory cells when compared to control group $(\mathrm{p}<0.05)$.

At 14 days, only the $0.9 \%$ sterile saline group showed a similar result to that of the control group $(\mathrm{p}>0.05)$. At this time, the $2.5 \% \mathrm{NaOCl}, 5.25 \% \mathrm{NaOCl}$ and $2.0 \%$ chlorhexidine gel groups remained with a higher mean number of inflammatory cells compared to the control group $(\mathrm{p}<0.05)$. The $2.0 \%$ chlorhexidine solution group presented a milder inflammatory response but still higher than that of the control group $(\mathrm{p}<0.05)$.

At 30 days, only the $5.25 \% \mathrm{NaOCl}$ group showed a significant mean number of inflammatory cells compared to the control group.

\section{DISCUSSION}

Several microorganisms found in the root canal system may be removed by the mechanical action of endodontic instruments. Nevertheless, due to the complexity of root canal anatomy, even after meticulous mechanical procedures, microorganisms located deeply in the dentinal tubules cannot be removed. For this reason, a range of substances have been used as irrigating solutions during root canal preparation to remove debris and necrotic pulp tissue remnants and to eliminate microorganisms that cannot be reached by mechanical instrumentation. An ideal endodontic irrigant must present favorable characteristics including maximum tissue dissolving capacity and antibacterial activity, and must induce mild or no inflammatory response in the tissues ${ }^{14,25,27}$. Therefore, the evaluation of tissue inflammatory response is important because inflammation is the first part of the healing process, which justifies the study of the inflammatory progression after different stimuli, including irrigating solutions ${ }^{20}$. The importance of these studies can be attributed to the fact that irrigant extrusion into surrounding periodontal tissues can occur in case of perforations and improper techniques or even in teeth with fully developed roots.

Therefore, tissue reaction induced by different endodontic irrigants was compared in present study. It was found that the control group (no injection) induced mild or no reaction in the subcutaneous tissue and that this process did not change at the different experimental periods. Likewise, other studies have reported only a very mild inflammatory reaction at the site of penetration with the needle of an empty syringe ${ }^{19,27}$, suggesting that this reaction occurred due to a mechanical trauma caused by the puncture itself.

In the present study, the $0.9 \%$ sterile saline group showed a mild inflammatory response with a significant increase in the mean number of inflammatory cells only at $48 \mathrm{~h}$. These findings are in agreement with those reported elsewhere ${ }^{27,30}$, suggesting that saline promoted a favorable reaction of connective tissues and can be considered as material biocompatible since tissue repair occurred 14 and 30 days.

The $2.0 \% \mathrm{NaOCl}$ and $2.0 \%$ chlorhexidine gluconate groups presented a moderate connective tissue inflammatory reaction. Although the mean number of inflammatory cells was considered significant at $48 \mathrm{~h}$ and 14 days, it could be observed a decrease in the number of inflammatory cells at 14 and 30 days, suggesting an ongoing connective tissue repair process. A similar outcome was observed at 14 days in other studies, which evaluated $0.12 \%$ chlorhexidine gluconate as an irrigating solution ${ }^{27,30}$. In these cases, the inflammatory response was at the highest level $48 \mathrm{~h}$ later, whereas the level of inflammation dropped by the end of the second week ${ }^{27,30}$. On the other hand, another study $^{27}$ found that $1 \%$ chlorhexidine gluconate was less toxic, less irritating and induced a faster regeneration than $0.5 \% \mathrm{NaOCl}$. It has also been demonstrated that chlorhexidine gluconate had no less antibacterial effect than 
$\mathrm{NaOCl}$ and that, because of its lower toxicity, should be preferred in root canal therapy, especially in cases of immature teeth ${ }^{12}$.

Although chlorhexidine gluconate has been indicated as an effective irrigating solution due to its favorable properties $^{4,5,12,15,17}$, the literature has suggested that, in some situations, this solution is not able to dissolve pulp tissues $^{6,14}$. Therefore, to solve this deficiency, some authors have recommended the combined use of $\mathrm{NaOCl}$ and chlorhexidine ${ }^{14}$ or the use of chlorhexidine gel ${ }^{1,6-9,13,18,22,28}$. The use of a viscous irrigant has been suggested because viscosity would compensate for the incapacity of chlorhexidine to dissolve pulp tissue by promoting a better mechanical cleansing of the root canal and removing dentin debris and tissue remnants. It would also promote a better lubricating action and improve the antimicrobial property ${ }^{6,26}$.

In the present study, it was also found that $2.0 \%$ chlorhexidine gluconate gel presented a mild initial inflammatory response that increased at $48 \mathrm{~h}$ and 14 days and decreased at 30 days. These results can be explained by the fact that the viscous bases used in these irrigants have little solubility in water. Thus, this finding suggests that chlorhexidine gel can promote a higher inflammatory response in the connective tissue because its clearance by the tissue occurs slower than the liquid presentation of the same substance.

Chlorhexidine gluconate gel has been extensively used in dentistry with good results in caries control by reducing Streptococcus mutans and Lactobacillus species, and as an adjuvant in periodontal therapy by controlling Grampositive and Gram-negative bacterial growth ${ }^{2}$.The use of chlorhexidine gel in endodontics has been suggested in few studies, with a good performance as an intracanal medication $^{13,22}$ or as an irrigant ${ }^{6,9,18,28}$. Despite the lack of studies evaluating the biocompatibility of this material, chlorhexidine gel has been shown to present a great potential for use as a routine endodontic irrigant as it has low toxicity and a wide antimicrobial spectrum ${ }^{6}$.

$5.25 \% \mathrm{NaOCl}$ presented a higher inflammatory response that remained up to the 30 -day period. It has been reported that $5.25 \% \mathrm{NaOCl}$ solution promotes an irritating effect on the periapical tissues and that, at the end of the second week of evaluation, foreign body granuloma formation occurred $^{30}$. In the same way as observed in the present investigation, other studies have reported that the number of inflammatory cells remained elevated at the sites treated with $5.25 \% \mathrm{NaOCl}$ even 14 days after injection, and that complete healing was not observed ${ }^{19,27,30}$. Also evaluating the toxic effect of $5.25 \% \mathrm{NaOCl}$, a previous study showed that in sites injected with this solution, tissue regeneration occurred at a slower rate when compared to the sites injected with $2.0 \%$ chlorhexidine gluconate. It has also been reported that $2.0 \%$ chlorhexidine gluconate displayed residual antibacterial activity and was more powerful and less toxic than $5.25 \% \mathrm{NaOCl}^{19}$. Taken together, these results support the idea that $5.25 \% \mathrm{NaOCl}$ promotes a toxic effect on connective tissue and should not be considered as an ideal root canal irrigant, especially when compared to other chemical agents that have favorable properties, such as biocompatibility.

\section{CONCLUSIONS}

In conclusion, the results of the present study indicate that $5.25 \% \mathrm{NaOCl}$ was the most toxic endodontic irrigant to rat subcutaneous connective tissue and the other solutions had a similar behavior at the end of the 30-day evaluation period.

\section{REFERENCES}

1- Ballal V, Kundabala M, Acharya S, Ballal M. Antimicrobial action of calcium hydroxide, chlorhexidine and their combination on endodontic pathogens. Aust Dent J. 2007;52(2):118-21.

2- Bondestam O, Gahnberg L, Sund ML, Linder L. Effect of Chlorhexidine gel treatment on the prevalence of Mutans streptococci and lactobacilli in patients with impaired salivary secretion rate. Spec Care Dentist. 1996;16:123-7.

3- Ehrich GD, Brian D, Walker WA. Sodium hypochlorite accident: inadvertent injection into the maxillary sinus. J Endod. 1993;19:1802 .

4- Estrela CR, Estrela C, Reis C, Bammann LL, Pecora JD. Control of microorganisms in vitro by endodontic irrigants. Braz Dent J. 2003;14:187-92.

5- Estrela C, Ribeiro RG, Estrela CR, Pecora JD, Sousa MD Neto. Antimicrobial effect of $2 \%$ sodium hypochlorite and $2 \%$ chlorhexidine tested by different methods. Braz Dent J. 2003;14:58-62.

6- Ferraz CC, Gomes BP, Zaia AA, Teixeira FB, Souza FJ Filho. In vitro assessment of the antimicrobial action and the mechanical ability of chlorhexidine gel as an endodontic irrigant. J Endod. $2001 ; 27(7): 452-5$.

7- Gomes BPFA, Ferraz CCR, Zaia AA, Souza FJ Filho. Variations in the susceptibility of selected microorganisms to endodontic irrigants. J Endod. 1999;25:299.

8- Gomes BPFA, Ferraz CCR, Viana ME, Berber VB. Teixeira FB, Souza FJ Filho. In vitro antimicrobial activity of several concentrations of sodium hypochlorite and chlorhexidine gluconate in the elimination of Enterococcus faecalis. Int Endod J. 2001;34:424-8.

9- Gurgel ED Filho, Vivacqua-Gomes N, Gomes BP, Ferraz CC, Zaia AA, Souza FJ Filho. In vitro evaluation of the effectiveness of the chemomechanical preparation against Enterococcus faecalis after single- or multiple-visit root canal treatment. Braz Oral Res. 2007;21(4):308-13

10- Heiling I, Chandler NP. Antimicrobial effect of irrigant combinations within dentinal tubules. Int Endod J. 1998;31:8-14.

11 - Hülsmann M, Hahn W. Complications during root canal irrigation: literature review and case reports. Int Endod J. 2000;33:186-93.

12- Jeansonne MJ, White RR. A comparison of 2.0\% chlorhexidine gluconate and $5.25 \%$ sodium hypochlorite as antimicrobial endodontic irrigants. J Endod. 1994;20:276-8. 
13 - Krithikadatta J, Indira R, Dorothykalyani AL. Disinfection of dentinal tubules with $2 \%$ chlorhexidine, $2 \%$ metronidazole, bioactive glass when compared with calcium hydroxide as intracanal medicaments. J Endod. 2007;33(12):1473-6.

14- Kuruvilla JR, Kamath MP. Antimicrobial activity of $2.5 \%$ sodium hypochlorite and $0.2 \%$ chlorhexidine gluconate separately and combined as endodontic irrigants. J Endod. 1998;24:472-6.

15 - Leonardo MR, Tanomaru M Filho, Silva LAB, Nelson P Filho, Bonifácio $\mathrm{KC}$, Ito IY. In vivo antimicrobial activity of $2 \%$ chlorhexidine used as a root canal irrigating solution. J Endod. 1999;25:167-71

16- Lillie RD. Histopathologic technique and practical histochemistry. 2nd ed. New York: Blakinston; 1954

17- Ohara PK, Torabinejad M, Kettering JD. Antibacterial effects of various endodontic irrigants on selected anaerobic bacteria. Endod Dent Traumatol. 1993;9:95-100.

18- Oliveira DP, Barbizam JV, Trope M, Teixeira FB. In vitro antibacterial efficacy of endodontic irrigants against Enterococcus faecalis. Oral Surg Oral Med Oral Pathol Oral Radiol Endod. 2007;103(5):702-6.

19- Önçag O, Hosgör M, Hilmioglo S, Zekioglu O, Eronat C, Burhanoglu D. Comparison of antibacterial and toxic effects of various root canal irrigants. Int Endod J. 2003;36:423-32.

20 - Robbins SL, Kumar V. Inflammation and repair. In: Robbins SL, Cotran RS, Kumar V, Schoen FJ. Robbins pathologic basis of disease. Philadelphia: WB Saunders; 1994.

21 - Siqueira JF Jr, Machado AG, Silveira RM, Lopes HP, Uzeda M. Evaluation of the effectiveness of sodium hypochlorite used with three irrigation methods in the elimination of Enterococcus faecalis from the root canal in vitro. Int Endod J. 1997;30:279-32.

22- Siqueira JF Jr, Uzeda M. Intracanal medications: evaluation of the antibacterial effects of chlorhexidine, metronidazole, and calcium hydroxide associated with three vehicles. J Endod. 1997;23:167-9.

23 - Siqueira JF Jr, Lima KC, Magalhães FAC, Lopes HP, Uzeda M. Mechanical reduction of the bacterial population in the root canal by three instrumentation techniques. J Endod. 1999;25:332-5.

24- Spangberg L, Engstrom B, Langeland K. Biologic effect of dental materials. Part III. Toxicity and antimicrobial effect of endodontic antiseptics in vitro. Oral Surg Oral Med Oral Pathol. 1973;36:85671 .

25- Thomas AM, Chandra S, Chandra S, Pandey RK. Elimination of infection in pulpectomized deciduous teeth: short term study using iodoform paste. J Endod. 1994;20:233-5.

26- Tucker JW, Mizrahi S, Seltzer S. Scanning electron microscopic study of the efficacy of various irrigation solutions: urea, Tubulicid Red, and Tubulicid Blue. J Endod. 1976;2:71-8.

27- Türkün M, Gökay N, Özdemir N. Comparative investigation of the toxic and necrotic tissue dissolving effects of different endodontic irrigants. Istanbul Univ Dishekim Fak Derg. 1998;32:87-94.

28 - Wang CS, Arnold RR, Trope M, Teixeira FB. Clinical efficiency of $2 \%$ chlorhexidine gel in reducing intracanal bacteria. J Endod. 2007;33(11):1283-9.

29- Williams CECS, Reid JS, Sharkey SW, Saunders WP. In vitro measurement of apically extruded irrigant in primary molars. Int Endod J. 1995;28:221-8.
30- Yesilsoy C, Whitaker E, Cleveland D, Philips E, Trope M. Antimicrobial and toxic effects of established and potential root canal irrigant. J Endod. 1995;21:513-5. 